\title{
Rola i działalność Centralnego Towarzystwa Rolniczego w procesach modernizacyjnych wsi Królestwa Polskiego w latach 1907-1914
}

\author{
The Role and Activity of the \\ Centralne Towarzystwo Rolnicze \\ in the Modernization Processes of the \\ Rural Areas in the Kingdom of Poland \\ Between 1907-1914
}

Pierwsze Królewskie Towarzystwo Rolnicze zostało założone w 1738 r. w Anglii. Zajmowało się pracami związanymi z oświatą rolną, w tym wystawami i pokazami. Organizowało pokazy - konkursy dobrej orki oraz wspierało wydawnictwa rolnicze. Za przykładem Anglii powstały takie towarzystwa we Francji, Danii i Niemczech, docierając z czasem także do Stanów Zjednoczonych'.

Na początku XX w. na ziemiach polskich znaczną rolę w życiu gospodarczym, jak i politycznym odegrały zrzeszenia rolnicze. W i8ı r. w Warszawie powstało Warszawskie Królewskie Towarzystwo Gospodarczo-Rolnicze, którego inicjatorem, założycielem był Stanisław Staszic, oraz Towarzystwo Kredytowe Ziemskie (I825) założone dzięki staraniom księcia Ksawerego Druckiego-Lubeckiego, ówczesnego Ministra Skarbu Królestwa Polskiego. Zadaniem Towarzystwa było: „spłacenie ciążących na prywatnej własności długów, a tem samem zachowanie przy ziemi ówczesnych właścicieli dóbr". Jednak dopiero druga połowa XIX w. przyniosła zauważalny roz-

I J. Socha, Dziatalność Centralnego Towarzystwa Rolniczego w dziedzinie oświaty rolniczej 1907-I927, Łódź 1994, s. 3 .

2 Cyt. za: I. Krasińska, Rola i dziatalność Okręgowego Towarzystwa Rolniczego w Radomiu w modernizowaniu wsi guberni radomskiej w latach Igo6-19I4, [w:] Dwór-wieś-plebania na ziemiach polskich wXIX i XX wieku. Profesorowi Mieczystawowi B. Markowskiemu w trzydziestolecie pracy naukowej, red. W. Caban i in., Kielce 2003, s. 98. 
wój w działalności tego typu towarzystw. W i89i r. powstało Krakowskie Towarzystwo Rolnicze ${ }^{3}$, następnie Towarzystwo Gospodarcze w Poznaniu (1867). Natomiast w Warszawie swoją działalność prowadziło Towarzystwo Rolnicze $^{4}$ powstałe I3 XI I 858 r. i działające do 8 X I86I r. Krótki okres aktywności wystarczył jednak, aby rozwinąć efektywne metody działalności oświatowej, co odzwierciedliło się w organizowaniu konkursów, urządzaniu wystaw rolniczych oraz w edycji „Roczników Gospodarstwa Krajowego”s.

W I86I r. polityka caratu doprowadziła do rozwiązania Towarzystwa Rolniczego w Warszawie, skutkiem czego rolnictwo w Królestwie Polskim pozbawione zostało własnej organizacji ${ }^{6}$. Niewielką namiastką, już rozwiązanego Towarzystwa, była Sekcja Rolna, utworzona w I89o r., grupująca w swych szeregach postępowych ziemian Królestwa Polskiego. Przewodniczącym Sekcji został Aleksander Kłobukowski, trzy lata później stanowisko to objął Tadeusz Kowalski, a w roku 1900 Stanisław Chełchowski Sekcja Rolna stała się ogniskiem spraw rolniczych, w tym krzewienia wiedzy rolniczej Kongresówki. Prowadziła działalność wydawniczą. Co roku wychodził jej organ prasowy zatytułowany „Prace Sekcji Rolnej”, w którym umieszczane były sprawozdania poszczególnych Delegacji (I8 Delegacji stałych), referaty i prace monograficzne rolnicze ${ }^{8}$. W i 896 r. z inicjatywy Sekcji Rolnej „zrodził się” projekt utworzenia syndykatu rolniczego, który obejmowałby wszystkie dziesięć guberni Królestwa Polskiego. Projekt ten został przedstawiony i omówiony na posiedzeniu Oddziału Towarzystwa Popierania Rosyjskiego Przemysłu i Handlu 17 X I896 r. w Warszawie?.

W latach I 897-ı 898 władze carskie wydały dwie ustawy o syndykatach i towarzystwach gubernialnych, które zezwalały na tworzenie spółek rolnych. Ustawa o syndykatach określała działalność handlową, zajmującą się zaopatrzeniem rolnictwa, zbytem produktów rolnych, a także działalnością pożyczkową ${ }^{10}$. W myśl ustawy o towarzystwach gubernialnych planowane były prace nad rozwojem rolnictwa i przemysłu, prowadzenie placówek

3 Pamiętnik Towarzystwa Rolniczego Krakowskiego za czas od r. 1845 do r. I895, zestawił J.A. Lippoman, Kraków I898, s. I5.

4 J. Socha, Dziatalność..., s. 4.

5 W. Grabski, Historia Towarzystwa Rolniczego I858-I86I r., t. 2, Warszawa 1904, s. I.

6 J. Socha, Centralne Towarzystwo Rolnicze 1907-1927, Łódź 2011, s. 5.

7 Z. Gloger, Pisma rozproszone, Białystok 2016, t. III, s. I50; P. Kaszubowski, Potężny w duchu ipotężny w ciele. Opowieść o Stanistawie Chetchowskim, Przasnysz 2007.

8 J. Socha, Centralne..., s. 6.

9 S. Dzięciołowski, Centralne Towarzystwo Rolnicze w Królestwie Polskim i jego polityka agrarna 1906-1918, Warszawa 1981, s. 27-28.

Io Rocznik Statystyczny Królestwa Polskiego z uwzględnieniem innych ziem polskich, pod kier. E. Strasburgera, Warszawa i916, s. 231. 
doświadczalnych, upowszechnianie wiedzy rolniczej, organizowanie wystaw i konkursów ${ }^{\text {II }}$ Już w kwietniu I899 r. zaczęły powstawać pierwsze ziemiańskie stowarzyszenia rolnicze. Początkowo w guberni siedleckiej, kieleckiej oraz łomżyńskiej jako towarzystwa rolnicze, natomiast w guberniach radomskiej i lubelskiej powstały spółki rolne zwane syndykatami. W ten sposób w latach I899-I90I w całym Królestwie Polskim zorganizowano sieć sprawnie działających ziemiańskich towarzystw rolniczych ${ }^{\mathrm{12}}$. Równocześnie w okresie tym na terenie Kongresówki zaczęły powstawać chłopskie spółki rolnicze ${ }^{13}$, nad którymi patronat objęli ziemianie i księża.

Pierwsza tego typu spółka powstała w I899 r. we wsi Wola Bukowska koło Miechowa (gubernia kielecka). Inicjatorem zawiązania spółki był agronom, działacz społeczny i publicysta Gabriel Godlewski. Celem spółki było nabywanie maszyn i narzędzi rolniczych, kwalifikacja ziarna siewnego oraz inwentarza rozpłodowego ${ }^{\mathrm{I}}$.

Jednak decydujący wpływ na rozwój spółek chłopskich miał ukaz carski z 4 III 1906 r., zezwalający na zakładanie wiejskich stowarzyszeń rolniczych w Królestwie Polskim. Stwarzał on nową sytuację prawną w dziedzinie gospodarczej, w której określone zostały kwalifikacje prawne i zasady rejestracji towarzystw oraz kółek rolniczych ${ }^{\text {Is }}$. Ukaz ten od strony formalnej dawał możliwość zakładania rolniczych towarzystw okręgowych na terenie jednego lub kilku powiatów, co w znacznym stopniu przyspieszyło powstanie Centralnego Towarzystwa Rolniczego (CTR).

Zarys ustawy oraz ogólny profil organizacyjny CTR został przygotowany przez Sekcję Rolną i znany był od kilku lat. Jednak po wdrożeniu w życie ukazu marcowego z 1906 r., w związku z nowymi warunkami prawnymi, powołano komisję założycielską, która miała za zadanie opracować ustawę CTR. W czerwcu komisja wystąpiła do Warszawskiej Komisji Gubernialnej do Spraw Towarzystw i Związków z podaniem o zarejestrowanie. Komisja na posiedzeniu II III 1906 r. podanie to oddaliła. Dopiero nowa wersja ustawy,

II J. Socha, Centralne..., s. 7 .

I2 J. Borkowski, A. Gurwicz, Kótka rolnicze w II Rzeczypospolitej, Warszawa I978, s. 229.

I3 Na Lubelszczyźnie pierwszym zrzeszeniem tego typu była „Zgoda”, zorganizowana w I90I r. w Nałęczowie (pow. puławski) przez Stanisława Śliwińskiego z sąsiadującego z uzdrowiskiem Antopola. Korzystając z doświadczeń spółki „Jutrzenka”, powstałej w I899 r. w Miechowie, ziemianin zachęcił kilkudziesięciu włościan do wspólnej pracy. A. Przegaliński, Zarys dziatalności oświatowej Lubelskiego Towarzystwa Rolniczego w latach Igos-19I4, "Studia z Historii Społeczno-Gospodarczej” 2010, t. vII, s. 43.

I4 M. Mysiakowski, Spotecznik z Klic, czyli rzecz o Michale Ignacym Bojanowskim (1865-1932), „Rocznik Mazowiecki” 2006, t. I8, s. I57; S. Wojciechowski, Historia spótdzielczości polskiej od I9I4 roku, Warszawa 1939, s. 219.

I5 J. Socha, Centralne..., s. 9; S. Dzięciołowski, dz. cyt., s. 45. 
bardziej precyzyjna w paragrafy i obszerniejsza, została przyjęta. Centralne Towarzystwo Rolnicze zostało zalegalizowane na podstawie postanowienia Urzędu do Spraw Stowarzyszeń Guberni Warszawskiej z 27 X 1906 r. ${ }^{16}$ W roli oficjalnego wnioskodawcy i założyciela wystąpił Stanisław Dzierzbicki, radca Komitetu Towarzystwa Kredytowego Ziemskiego (TKZ). Dalszymi przedstawicielami C T R byli: Józef Jeziorański, Witold Marczewski z guberni piotrkowskiej, Stanisław Wroński z guberni warszawskiej, Aleksander Karszo-Siedlewski z radomskiej, Mścisław Godlewski z kieleckiej oraz Władysław Gawroński z suwalskiej. Wśród założycieli byli także prezesi towarzystw gubernialnych m.in.: Stanisław Chełchowski z towarzystwa płockiego, Aleksander Makowski - z siedleckiego, Wojciech Wyganowski - zkaliskiego, Juliusz Florkowski - z lubelskiego, Kazimierz Kisielewski - z łomżyńskiego, Tomasz hr. Potocki - z suwalskiego oraz Juliusz hr. Tarnowski - z radomskiego. W gronie tym znajdowali się także reprezentanci Sekcji Rolnej na czele z prezesem Stanisławem Chaniewskim z guberni płockiej, wiceprezesem Antonim Bielińskim $-\mathrm{z}$ radomskiej i Michałem Natansonem z guberni warszawskiej ${ }^{17}$.

Ustawa głosiła, że celem CTR jest „zespolenie usiłowań i prac rolników związanych w Towarzystwach rolniczych okręgowych dla podniesienia stanu rolniczego i gospodarstwa rolnego" oraz reprezentowanie interesów rolnictwa wobec władz ustawodawczych i wykonawczych. Przewidziano także „nadawanie ogólnego kierunku produkcji rolnej kraju”, wprowadzenie specjalizacji lokalnych, a także oddziaływanie na strefę stosunków handlowo-rolniczych i robotniczych. Centralne Towarzystwo Rolnicze postanowiło więc przystąpić do inicjatyw prawodawczych i „orędownictwa interesów rolniczych w stosunkach urzędowych" ${ }^{{ }^{18}}$. W działalności organizacyjno-gospodarczej wpisano rozwijanie związków terenowych, kooperatyw, kółek włościańskich istowarzyszeń. Działalność społeczna w głównej mierze polegała na szerzeniu oświaty oraz popularyzacji obecnych osiągnięć agrotechnicznych ${ }^{\mathrm{19}}$.

W koncepcji ustawy CTR było związkiem rolniczych towarzystw okręgowych. Za takie uważano także towarzystwa gubernialne. Dlatego też w myśl ustawy członkostwo w CTR nabywano poprzez wstąpienie do któregoś z towarzystw terenowych. Powstały dwie kategorie członkostwa: wyższa i niższa. Pierwszą kategorię - członków rzeczywistych, honorowych i wspierających - tworzyli wszyscy wstępujący do okręgowych towarzystw rolniczych. Drugą kategorię - członków czynnych - tworzyli ci, którzy wstępowali do kółek

16 Tamże, s. 70; J. Socha, Centralne..., s. 9.

17 S. Dzięciołowski, dz. cyt., s. 70.

18 Tamże, s. 49-50.

19 Wkrzeszenie Centralnego Towarzystwa Rolniczego, „Tygodnik Ilustrowany” 1907, nr II, s. 230; S. Dzięciołowski, dz. cyt., s. 49-50. 
rolniczych. Członkowie CTR tworzyli Ogólne Zebranie. Był to organ o charakterze doradczym, zbierający się raz w roku. Organem kierowniczym Towarzystwa była Rada Główna, która składała się z prezesów towarzystw terenowych i delegatów w liczbie jeden na trzydziestu członków. Rada Główna wybierała dwunastoosobowy Komitet będący organem wykonawczym oraz sześcioosobowe Prezydium, które kierowało działalnością Towarzystwa. Na zewnątrz wobec władz i instytucji Komitet reprezentował CTR, jednak główną i bezpośrednią rolę odgrywał prezes i jego dwaj zastępcy. Na czele Prezydium stał prezes Komitetu, który zarazem był prezesem Towarzystwa ${ }^{20}$.

Centralne Towarzystwo Rolnicze mogło nabywać i sprzedawać nieruchomości, pozyskiwać środki finansowe ze składek członków oraz z dotacji, prowadzić bibliotekę, gromadzić materiały do celów naukowych i historycznych ${ }^{21}$.

Ustawa przewidywała także połączenie, w miarę możliwości, wszystkich organizacji, w skład których wchodzili producenci rolni. Centralne Towarzystwo Rolnicze jako stowarzyszenie producentów w swoich założeniach miało reprezentować całe rolnictwo Królestwa Polskiego, z zastrzeżoną wyłącznością w tym zakresie. W interesie członków miała być prowadzona polityka gospodarcza, która oddziaływałaby na rynek towarowy i rynek pracy. W ustawie nie było mowy o łączeniu się ze stowarzyszeniami pracowników rolnych, tym bardziej z robotniczymi. Zapowiadane „współdziałanie w regulacji i poprawie stosunków służbowych i robotniczych”, a także „zajęcie się losem" tych pracowników nie przewidywało udziału samych zainteresowanych. Szereg artykułów ustawy CTR wytyczało linię działalności fachowo-zawodowej i stanowiło o drugiej ważnej funkcji Towarzystwa jako ośrodka kształcenia fachowego wszystkich szczebli, centrum doświadczalnictwa, prac badawczych oraz wymiany myśli zawodowej. Popularyzacja i działalność oświatowa prowadzona przez CTR skierowana była głównie do włościan w celu racjonalizacji gospodarstwa drobnej własności ${ }^{22}$.

Otwarcie CTR poprzedziły dwa zjazdy: Zjazd Agrarny i zjazd przedstawicieli kółek i spółek chłopskich. Zjazdy te wywarły duży wpływ na kierunek i zakres praktycznej działalności tegoż Towarzystwa. Oficjalna inauguracja CTR odbyła się II III 1907 r. w Warszawie podczas posiedzenia Rady Głównej. W posiedzeniu uczestniczyło II 8 delegatów, którzy reprezentowali ok. 3400 członków, zrzeszonych w ośmiu towarzystwach gubernialnych i pięciu okręgowych $^{23}$. Przewodniczącym zebrania byłziemianin, krzewiciel intensywnej

20 J. Socha, Centralne..., s. 9-ı; tenże, Stownik biograficzny dziataczy Centralnego Towarzystwa

Rolniczego (1907-1929), Łódź 2003, s. 9; tenże, Dziatalność..., s. 5; S. Dzięciołowski, dz. cyt., s. 50.

2I Ustawa Centralnego Towarzystwa Rolniczego w Królestwie Polskim, Warszawa 1907, s. 6-7.

22 S. Dzięciołowski, dz. cyt., s. 72.

23 Tamże, s. 72, 58 . 
gospodarki rolnej, znawca hodowli koni Leon Przanowski² ${ }^{24}$ Mowę wstępną wygłosił Stanisław Chełchowski. Nawiązał w niej do inicjatyw w tworzeniu ognisk zbiorowego życia rolniczego, takich jak: Towarzystwo Gospodarczo-Rolnicze z lat I810-I817, zjazdy ziemiaństwa w majątku Andrzeja hr. Zamoyskiego w Klemensowie (I843-I847), a także osiągnięcia Towarzystwa Rolniczego z lat i858-i86I, którym kierował A. Zamoyski²5. S. Chełchowski wskazał też na zmiany, jakie zaszły we wszystkich dziedzinach życia na przestrzeni ostatnich 50 lat, oraz przypomniał o groźbie rewolucji agrarnej $^{26}$. W związku z tym zaproponował, aby rozszerzyć zakres działalności Towarzystwa, a struktury dostosować do nowych zadań, w szczególności skierowanych do chłopów. Jako jedne z najważniejszych problemów z pozycji solidaryzmu narodowego stawiane przez $S$. Chełchowskiego były potrzeby gospodarcze mniejszej własności i potrzeby społeczno-oświatowe wsi $^{27}$. W wystąpieniu swym podkreślił m.in., że:

Towarzystwo rolnicze przed 50 laty powstało $\mathrm{w}$ okresie nadziei na poważne reformy społeczne i polityczne a więc w momencie, który miał duże podobieństwa do chwili, którą obecnie przeżywamy [...]. Na podatnym gruncie stosunków robotniczych rozwija się agitacja przewrotna, która do osłabienia jedności w dążeniach narodowych znacznie się przyczyniła [...], dziś musimy bronić się przed wytworami wschodniej kultury, jak ideą upaństwowienia i wywłaszczania gruntów ${ }^{28}$.

W swojej wypowiedzi nawiązał też do zadań organizacyjnych CTR, stwierdzając:

Konieczność uwzględniania potrzeb zrzeszeniowych drobnej własności ziemskiej otwiera nam szerokie pole działania. Zaufanie, jakie zdołaliśmy w nich wzbudzić na polu akcji politycznej i przy wyborach, w walce o prawa na polu

24 E. Ścibor, Życie i dziatalnośćspoteczno-obywatelska Leona Przanawskiego (I844-19I4), „Bibliotekarz Lubelski” 2010, R. LVIII, s. 49-63.

25 J. Socha, Centralne..., s. Io.

26 Rewolucja agrarna - całokształt procesów prowadzących do przekształcenia rolnictwa tradycyjnego, feudalnego i mało wydajnego w rolnictwo nowoczesne; rewolucja agrarna obejmuje: likwidację feudalizmu na wsi i utrwalenie się stosunków własnościowych typowych dla kapitalizmu (uwłaszczenie chłopów), zastąpienie feudalnej struktury społecznej strukturą klasową oraz przeobrażenie techniczno-produkcyjne, np. wprowadzenie płodozmianu, upowszechnienie się nawożenia, rozpowszechnienie nowych upraw, zastosowanie nowoczesnych narzędzi i maszyn. B. Snoch, Stownik szkolny. Terminy i pojęcia historyczne, Warszawa 1990, s. 131-132.

27 S. Dzięciołowski, dz. cyt., s. 74.

28 S. Chełchowski, Mowa wypowiedziana na pierwszym zebraniu Rady Gtównej CTR, „Gazeta Rolnicza” ${ }_{1907,} \mathrm{nr}_{13}$, s. 218. 
pracy kulturalnej - w organizacji i prowadzeniu Macierzy Szkolnej zmusza nas z pełną wiarą podać rękę wyciągającym się do nas dłoniom, aby postawić ich obok siebie, jako obywateli, na których przyszłość kraju wspierać się będzie [...]. Opierając więc organizacje rolniczą o szerokie warstwy posiadaczy małorolnych musimy stanąć wobec nich jako równi wobec równych i w tym duchu organizacja Centralnego Towarzystwa Rolniczego jest pomyślana i w tym powinna być przeprowadzona w życie ${ }^{29}$.

Dalsza część wypowiedzi S. Chełchowskiego dotyczyła odnalezienia równowagi między dążeniami centralizacyjnymi CTR a decentralizacyjnymi towarzystw terenowych. W przemówieniu nawiązał także do swych koncepcji samorządu gospodarczego ${ }^{3 \circ}$.

W drugim dniu obrad Rady, I2 III 1907 r., przystąpiono do wyborów Prezydium oraz Komitetu. W tajnym głosowaniu na prezesa wybrano S. Chełchowskiego, który otrzymał ıoo głosów przy i 8 obecnych ${ }^{31}$. Wiceprezesami zostali S. Chaniewski i S. Dzierzbicki. W wyniku obrad powołano ponadto dwóch sekretarzy: Antoniego Wieniawskiego i Stanisława Czekanowskiego, natomiast ich zastępcą został Leon Lissowski. Do Komitetu weszli także: baron Zdzisław Heydel, Władysław Potocki, Juliusz Florkowski, ks. Seweryn Światopełk-Czetwertyński, Kazimierz Kisielnicki, Wojciech Wyganowski, Juliusz hr. Tarnowski, Ludomir Puławski, Stanisław Wroński oraz Stefan Bądzyński. O kolejności przystąpienia do Komitetu zadecydowała ilość głosów otrzymanych w wyborach ${ }^{32}$.

Dnia 23 III 1907 r. w drodze na zebranie Płockiego Towarzystwa Rolniczego zmarł nagle nowo obrany prezes CTR S. Chełchowski. Wobec tego zdarzenia I7 VI 1907 r. przystąpiono powtórnie do wyborów nowego prezesa oraz dokonano wyborów uzupełniających. W wyniku wyborów czerwcowych z 85 głosami na Ior możliwych prezesem został S. Czetwertyński. Po czerwcowych wyborach ze stanowiska wiceprezesa zrezygnował S. Dzierzbicki, tłumacząc się nawałem pracy. Na jego miejsce wybrano ziemianina, działacza społecznego i politycznego Mariana Kiniorskiego ${ }^{33}$ oraz przystąpiono do wcześniej odłożonych wyborów uzupełniających ${ }^{34}$.

\footnotetext{
29 Tamże, s. 219-220.

30 S. Dzięciołowski, dz. cyt., s. 74 .

3 I J. Socha, Centralne..., s. II.

32 S. Dzięciołowski, dz. cyt., s. 59; S. Dziewulski, Dzierzbicki Stanistaw, [w:] Polski Stownik Biograficzny, t. 6, Kraków 1948, s. I41; J. Socha, Stownik..., s. 65-66, 75-77; Wielka Encyklopedia Powszechna, t. 2, Warszawa 1963 , s. 754.

33 Z. Kaczmarek, Marszatkowie Senatu II Rzeczpospolitej, Warszawa I992, s. I68.

34 S. Dzięciołowski, dz. cyt., s. 6I.
} 
Stanowisko sekretarza powierzono Bogdanowi Zakrzewskiemu, wybrano także dwóch członków Komitetu: Wacława Gołembiowskiego i Leona Wiszniewskiego. Ich zastępcami zostali Leon Szeliński, Tomasz Siekulicki, Stanisław Wielowiejski oraz Władysław Grabski, który w dniu głosowania otrzymał najmniejszą liczbę głosów ${ }^{35}$.

S. Czetwertyński, obejmując funkcję prezesa na posiedzeniu I8 VI I907 r., wystąpił z przemową do zebranych. W wystąpieniu nawiązał do wcześniej wytyczonego przez poprzednika kierunku działania Towarzystwa. Mówił:

Praca nasza nie może uwzględnić interesów jednej warstwy, większej własności i przemożnej roztoczyć nad nią opieki. Pewne wyodrębnienie potrzeb jest tu konieczne z powodu innego stopnia kultury, innych wymagań, które innych wymagają środków ku zaspokojeniu, ale na ogół mamy rolnictwo krajowe, jako takie podnieść w wydajności i w zasobności pomnożonej. Sądzę, że sprawiedliwi będziemy, jeżeli w specjalną opiekę weźmiemy tych z nas, którzy dotychczasowo pomocy zupełnie pozbawieni byli, co bardzo rady pragną, tak chętni do wspólnej pracy się garną, a najliczniejsi są i najpracowitsi. Praca nasza winna być i będzie „narodowa”, na "narodowych ideałach oparta” ${ }^{36}$.

Już jesienią 1907 r. „Gazeta Rolnicza” opublikowała artykuł W. Grabskiego zatytułowany Zadania Centralnego Towarzystwa Rolniczego. Przed zamieszczeniem go w prasie został uprzednio uzgodniony z komitetem $\mathrm{CTR}^{37}$. W. Grabski przedstawił linię polityki agrarnej CTR, którą próbował rozpropagować wśród ziemiaństwa. Sam autor uważał, że: „Towarzystwo Centralne winno być postrzegane jako organ publiczny do spraw rolnictwa krajowego"38. W dalszej części tekstu czytamy:

W zakresie prawodawczym Centralne Towarzystwo Rolnicze ma zupełnie wyraźne zadania, odrębne od polskiej delegacji poselskiej w Petersburgu. Ostatnia może występować do Izby państwowej z projektami praw dla Królestwa, ale tylko ogólnego narodowego znaczenia. [...]. Wobec tego zadaniem CTR jest starać się, by w zakresie takich spraw, jak: komasacja, zniesienie serwitutów, parcelacja, kredyt, w sprawie prawa wodnego, sam rząd wystąpił z projektami praw dla naszego kraju wobec Izby państwowej. [...] W dziedzinie szkolnej CTR powinno powołać do życia szkołę normalną rolniczą dla

$35 Z$ Towarzystw i Instytucji Rolniczych, „Gazeta Rolnicza” 1907, nr 25, s. 417.

36 Mowa prezesa CTR (na otwarcie posiedzenia z I8 czerwca), „Gazeta Rolnicza” I907, nr 26, s. 425-426.

37 S. Dzięciołowski, dz.cyt., s. 77.

38 W. Grabski, Zadania Centralnego Towarzystwa Rolniczego, „Gazeta Rolnicza” 1907, nr 39, s. 64I. 
Królestwa, która by poziomem swoim sięgała typu szkoły wyższej, ale programem mieściła się w ramach szkoły średniej. Taka szkoła miałaby prawo otrzymywania subwencji rządowej [...]. Prócz tego CTR winno zachęcić jak najliczniejszych ziemian do zakładania niższych szkół rolniczych [...]. CTR powinno powołać do życia jedną normalną stację rolniczą, naukowo odpowiednio uposażoną z siecią pól doświadczalnych po kraju [...] założenie jednej, poważnie postawionej stacji doświadczalnej centralnej dla Królestwa jest bardzo wskazane, szczególnie w zakresie bakteriologii [...]. Należy założyć całą sieć stacji rozpłodowych buhajów i knurów dla włościan i uzyskać zapomogi na kupno buhajów i na ich utrzymanie [...]. CTR winno wziąć w swoje ręce sprawę melioracji publicznych krajowych, wymagających częściowych regulacji rzek dla nas. Wobec tego CTR winno żądać kredytu na uskutecznienie owych robót regulacyjno-osuszających w naszym kraju ${ }^{39}$.

Wraz z uformowaniem się CTR Sekcja Rolna przestała istnieć. Jej akta i wydawnictwa zostały przez CTR przejęte, a „Gazeta Rolnicza” od lipca 1907 r. stała się oficjalnym organem wydawniczym Towarzystwa ${ }^{\circ}$.

W latach 1907-I908 przy CTR działalność swoją rozpoczęły wydziały: Kółek Rolniczych, Społeczno-Ekonomiczny, Rolniczy, Hodowlany i Naukowo-Dydaktyczny. Przy założeniu wydziałów wykorzystano doświadczenia delegacji funkcjonujące do tej pory przy Sekcji Rolnej, uzupełniając ich skład fachowcami ze swego grona i wybranych stowarzyszeń specjalistycznych ${ }^{41}$. Zadania powołanych do życia wydziałów oraz ich konkretna działalność stały się przedmiotem dyskusji CTR, ale także prasy rolniczej.

Tymczasowy komitet Wydziału Kółek Rolniczych ukonstytuował się I9 VI 1907 r. Na czele Wydziału liczącego początkowo 27 członków stanęli: przewodniczący - Michał Natanson, sekretarzem został Sławomir Miklaszewski oraz Stefan Biedrzycki i S. Chaniewski, Aleksander Karszko-Siedlewski, Ignacy Kosiński, Wilhelm Meylert, Antoni Sempołowski, Jan Załuski i Stanisław Wroński jako członkowie ${ }^{42}$. Wybierając tymczasowy zarząd, polecono Komitetowi, aby zajął się „zorganizowaniem Wydziału, w taki sposób i w takim kierunku, aby po przerwie letniej, przy większej ilości członków stanąć mógł do pracy mającej już pewien nakreślony kierunek" ${ }^{33}$. Wydział Rolniczy, odzwierciedlając swe zadania, podzielił je na dwa nurty:

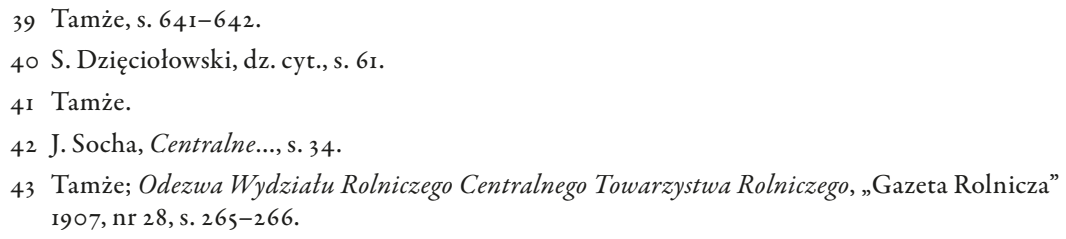


pierwszy dotyczył pracy samodzielnej, prowadzonej z inicjatywy samego Wydziału, natomiast drugi skupiony był na pracy wspólnej z Towarzystwami Rolniczymi Okręgowymi jako ich organ i rzecznik ${ }^{44}$. W takim rozumieniu swego zadania w zakresie pierwszego kierunku swego działania Wydział Rolniczy przedstawił wytyczne nadające podniesieniu wiadomości naukowych w zakresie rolnictwa pierwszorzędne znaczenie. Wydział planował wejść w jak najściślejszy kontakt z istniejącymi w kraju stacjami doświadczalnymi. Stacje te jako zasobnik wiedzy teoretycznej w pierwszej linii powołane były do szerzenia postulatów nauki mających znaczenie dla praktyki rolnej. Wydział we współpracy ze stacjami doświadczalnymi powinien szerzyć wiedzę zarówno słowem, jak i czynem. Powinno się to przejawiać w odczytach i kursach, z jednej strony, a w zbiorowych doświadczeniach polowych z drugiej ${ }^{45}$. Kolejnym punktem działalności Wydziału było szerzenie wiedzy rolniczej za pomocą słowa. W tym celu Wydział Rolniczy wraz z innymi Wydziałami CTR podczas comiesięcznych zebrań miał organizować odczyty z zakresu rolnictwa, ogłaszać na zebraniach wydziałowych sprawozdania z ruchu naukowego za granicą, uwzględniając przy tym kwestie ważne dla rolnictwa krajowego. Działalność Wydziału na rzecz rolnictwa przejawiała się w ogłaszaniu wyników prac doświadczalnych przeprowadzanych przez krajowe stacje doświadczalne. Wiedząc, że słowo drukowane w efektywny sposób rozpowszechnia wiedzę rolniczą, Wydział planował zająć się drukiem i rozpowszechnianiem broszur i większych dzieł. Wydział Rolniczy stanowić miał dla swych członków i dla rolników swoistego rodzaju biuro informacyjne wraz biurem porad, które udzielałyby informacji dotyczących organizacji gospodarstwa i wprowadzenia zmian w rolnictwie ${ }^{46}$.

Przy Wydziale Rolniczym CTR powstały następujące delegacje: szkolna, melioracyjna, gleboznawcza i mechaniczna. Delegacje te stanowiły organ doradczy dla Wydziału, a zakres ich działalności nie był z góry narzucony, wiązało się to z rozwojem prac w poszczególnych delegacjach. I5 X $1907 \mathrm{r}$. odbyło się zebranie organizacyjne Wydziału, na którym przedstawiono zadania zawiązanych delegacji. Delegacja szkolna zajmowała się udzielaniem informacji dotyczących zakładania i prowadzenia szkół rolniczych, opracowaniem programów nauczania, zbieraniem danych statystycznych, urządzaniem kursów, pogadanek i pokazów rolniczych, a także redagowaniem podręczników. Delegacja melioracyjna miała za zadanie opracowanie nowelizacji do prawa wodnego o wolnym przepływie wód; przygotowanie za-

\footnotetext{
44 Z Towarzystw i Instytucji Rolniczych, „Gazeta Rolnicza” 1907, nr 44, s. 731.

45 Tamże, s. 732.

46 Tamże.
} 
początkowanego przez Centralne Towarzystwo Rybackie projektu nowej ustawy wodnej; pracę nad projektowaniem melioracji; wszelkiego rodzaju regulację rzek; nawadnianie, osuszanie i zadrzewianie większych przestrzeni; udzielenie rad i wskazówek potrzebującym tego w zakresie melioracji. Delegacja gleboznawcza skupiła się na działaniach w Pracowni Gleboznawczej, której kierownikiem był Sławomir Miklaszewski. Przewodniczącym zarządu został Jan Załuski. Wykonywane tam prace dotyczyły badania gruntów i rozpowszechnienia wśród rolników zrozumienia konieczności poznania gruntów pod względem ich jakości. S. Miklaszewski zebrał i zbadał główne typy gleb guberni piotrkowskiej, powiatu zamojskiego guberni lubelskiej oraz przeprowadził badanie gleb powiatu hrubieszowskiego w okolicach Dołhobyczowa i Poturzyna. Badał też gleby na Węgrzech, skąd przywiózł liczne próbki. Naszkicował plan badań gleboznawczych, zapoczątkowanych wcześniej przez Polskie Towarzystwo Krajobrazowe w Górach Świętokrzyskich. W Pracowni Gleboznawczej zajęcia praktyczne odbywali słuchacze II kursu Wydziału Rolniczego Towarzystwa Kursów Naukowych. Delegacja mechaniczna kierowała testami nowych maszyn i narzędzi rolniczych, oceniała ich wartość praktyczną, urządzała konkursy, wystawy, a także ogłaszała wyniki prac zwracając uwagę rolników na stosowny wybór nowo wprowadzonych narzędzi i maszyn rolniczych ${ }^{47}$.

Posiadanie nowych i dobrych odmian roślin uprawnych było w tamtych czasach ważną potrzebą rolnictwa. Aby podnieść plony i osiągnąć jak największy dochód, Wydział Rolniczy w 1909 r. powołał Sekcję Nasienną. Do jej zadań należała opieka nad gospodarstwami zajmującymi się hodowlą i produkcją nasion siewnych. W skład zarządu Sekcji weszli: Aleksander Karszo-Siedlewski jako przewodniczący, Zdzisław Zieliński - sekretarz oraz członkowie: Jan Dłużewski, Stanisław Janasz i Jan Olędzki. Z inicjatywy Sekcji, a za zgodą komitetu CTR, zaczęto urządzać jarmarki nasienne. Działalność Sekcji przyczyniła się do zjednania uznania i zaufania wśród rolników. Świadczyć o tym mogły liczne pytania nadchodzące do Sekcji, a dotyczące spraw hodowlanych, sprzedaży i zakupu nasion oraz wyboru właściwych odmian ${ }^{4}$.

Równolegle z wyżej wymienionymi sekcjami przy Wydziale Rolniczym prace rozpoczął Wydział Hodowlany. II XI 1907 r. odbyło się zebranie organizacyjne, na którym powołany został zarząd. W jego skład weszli: Daniel

47 J. Socha, Centralne..., s. 34, 43; Z Towarzystw i Instytucji..., s. 732; Sprawozdanie Centralnego Towarzystwa Rolniczego w Królestwie Polskiem za rok 19og, Warszawa 1910, s. 19-20.

48 J. Socha, Centralne..., s. 38; J. Ryx, Uwagi nad programem Sekcji Nasiennej przy Wydziale Rolniczym CTR, „Gazeta Rolnicza” 1911, nr 25, s. 57-68; Sprawozdanie Centralnego Towarzystwa Rolniczego w Królestwie Polskiem za rok IgII, t. 4, Warszawa I9I2, s. 28. 
Janasza, Antoni Budny i Stanisław Wotowski. Z ramienia CTR do zarządu wszedł S. Chaniewski. Wydział został podzielony na sekcje chowu koni, owiec, bydła oraz trzody chlewnej. Do najważniejszych prac ogólnych Wydziału zaliczyć należy opracowany w $1908 \mathrm{r}$. Memoriat do wtadz dotyczący nowej ustawy weterynaryjnej oraz organizacji kursów dla asystentów kontroli obór. Początkowo kursy te prowadzone były w języku niemieckim, dlatego gromadziły niewielką liczbę słuchaczy, ale już rok później prowadzono je w języku polskim pod kierunkiem Karola Różyckiego. Z kolei zadaniem poszczególnych sekcji było podnoszenie poziomu hodowli, śledzenie postępów w tej dziedzinie oraz przeprowadzanie badań i doświadczeń, krzewienie wiedzy fachowej, urządzanie wystaw, pokazów i jarmarków, kształcenie asystentów kontroli, organizowanie związków hodowlanych i kółek kontroli, pośrednictwo w kupnie i sprzedaży inwentarza oraz szerzenie wiedzy przez odczyty, kursy i pogadanki ${ }^{49}$.

Wiosną 1909 r. Wydział zorganizował pierwszy ogólnokrajowy jarmark inwentarza żywego. Na jarmark ten dostarczono 66 koni, 209 sztuk bydła, 60 świń, 6 owiec oraz 50 sztuk drobiu ${ }^{50}$. Wydział Hodowlany CTR wziął natomiast udział w I Wszechrosyjskim Zjeździe Hodowców Bydła w Petersburgu. Delegatami Wydziału byli i stosowne referaty wygłosili S. Chaniewski i K. Różycki. Szczególne znaczenie miało wystąpienie drugiego prelegenta z referatem $O$ organizacji zwiazków kontroli obór w Królestwie Polskim. Przemówienie to wzmocniło pozycję polityczną CTR na gruncie rosyjskim ${ }^{\text {II }}$. Centralne Towarzystwo Rolnicze stało się dysponentem subwencji państwowych dla rolnictwa w całym Królestwie Polskim, które rosły proporcjonalnie do środków własnych, a pochodziły głównie ze składek i darów społecznych ${ }^{52}$.

W swojej działalności Wydział Rolniczy obejmował organizację odczytów, urządzanie pokazów maszyn rolniczych, a także prace Biura Porad Rolniczych i Komisji Praktyk Rolniczych. W pokazach tych udział brały firmy specjalizujące się w produkcji maszyn rolniczych, silników do nich oraz innych części zamiennych, warsztaty naprawcze i inne ${ }^{53}$. Uruchomiono

49 J. Socha, Centralne..., s. 46; S. Dzięciołowski, dz. cyt., s. 81; Sprawozdanie Centralnego Towarzystwa Rolniczego w Królestwie Polskiem za rok ıوı, Warszawa ı1ı, s. 35. Tematyka odczytów i pogadanek na przestrzeni lat była różna, przykładowo referaty wygłosili: Stefan Kazimierz Kowerski z Józwowa Oobchodzeniu się z obornikiem, Nikodem Budny z Jastkowa O hodowli trzody chlewnej, hr. Edmund Scipio del Campo z Brzezic O nawozach sztucznych. Zob. A. Przegaliński, dz. cyt., s. 42.

s० Z Towarzystw i Instytucji Rolniczych, „Gazeta Rolnicza” 1907, nr 47, s. 543-544.

ऽI J. Socha, Centralne..., s. 48.

52 Tamże.

53 Wśród przedsiębiorstw prezentujących sprzęt rolniczy były m.in.: Fabryka maszyn rolniczych T. Czarliński i R. Swiniarski, Towarzystwo Akcyjne T. Kowalski i A. Trylski, skład maszyn, 
szereg kursów długo - i krótkoterminowych, różnego stopnia, a także utworzono trzyletnie kursy stopnia wyższego, które odpowiadać miały wyższej szkole rolniczej ${ }^{54}$.

We wrześniu 1908 r. wyodrębniono z Wydziału Rolniczego - Wydział Doświadczalno-Naukowy z proponowanymi trzema sekcjami: doświadczalno-rolniczą, zootechniczną i wydawniczą. Jednak na zebraniu organizacyjnym zdecydowano się na powołanie tylko Sekcji Doświadczalno-Rolniczej. Kierownictwo Wydziału objęli I. Kosiński w roli przewodniczącego, S. Leśniowski jako zastępca i Z. Zieliński - sekretarz. Wydział skupiał wokół siebie rolników z wyższym wykształceniem, którzy posługiwali się metodami naukowymi w postaci samodzielnych badań teoretycznych lub praktycznych prób i doświadczeń. Początkowo Wydział liczył 52 członków, a w I9II r. już II5. W'śód nich znalazły się nie tylko osoby fachowo związane z doświadczalnictwem, ale i ziemianie gospodarujący na roli. Praca Wydziału koncentrowała się wokół koordynacji działalności istniejących już i powstających stacji rolniczych, ferm i pól doświadczalnych na terenie Królestwa Polskiego5s.

W czasie formowania się CTR na obszarze Kongresówki działalność prowadziły trzy stacje doświadczalne w: Sobieszynie, Kutnie oraz Chruszczewie. W chwili powstania CTR stacje doświadczalne miały za sobą okres podstawowych prac badawczych dotyczących stosowania nawozów mineralnych i pielęgnacji roślin. Stacje wykonywały liczne doświadczenia, tzw. prace zbiorowe na polach dworskich i włościańskich, służące każdej okolicy, wsi, folwarkowi w wytypowaniu najlepszych odmian i sposobu upraw roślin. W I908 r. wykonano IO2 doświadczenia zbiorowe w 40 gospodarstwach chłopskich pod kierunkiem stacji w Chruszczewie i w Kutnie. Rok później wykonano ich 57, a w roku I912 - I06 doświadczeń przeprowadzonych pod kierunkiem tych trzech stacji ${ }^{56}$.

Działalność CTR skupiona była nie tylko na pracach stacji, ale także na polach doświadczalnych. Prowadzone tam badania w dużej mierze dotyczyły prób uprawy buraków cukrowych, uprawy zbóż i ziemniaków ${ }^{57}$.

narzędzi rolniczych i nasion oraz warsztaty reparacyjne Alfreda Grodzkiego, Fabryka Narzędzi Gospodarczych Józefa Sucheni z Gidel, Syndykat Rolniczy Warszawski oraz Towarzystwo Fabryki Motorów „Perkun” w Warszawie.

54 Program Wydziatu Rolniczego CTR przedstawiony na zebraniu organizacyjnym przez przewodniczacego dla Michata Natansona, „Gazeta Rolnicza” 1907, nr 44, s. $731-733$.

55 J. Socha, Dziatalnośćc..., s. 45-46; S. Dzięciołowski, dz. cyt., s. 8I.

56 J. Socha, Dziatalność..., s. 46-54, 56.

57 S. Wykrętowicz, Przemyst cukrowy i jego rola wekonomice Polski Ludowej (1945-1960), Poznań 1967, s. I43; Zob. szerzej: H. Biały, Rola pól doświadczalnych w rozwoju rolnictwa Królestwa Polskiego iziem zabranych wXIX i początkach XX wieku, „Zeszyty Wiejskie” 2013, z. I8, s. 88-IO5. 
W czasie I wojny światowej działalność Wydziału Rolniczego uległa zahamowaniu, a prace skierowane zostały na takie działania, w których uwagę skupiono na naprawę szkód wyrządzonych przez działania wojenne ${ }^{58}$.

Do powstania Wydziału Społeczno-Ekonomicznego CTR w dużej mierze przyczynił się S. Dzierzbicki, który stanął na czele stosownej komisji, opracowując program i regulamin Wydziału. W początkowym okresie swego funkcjonowania (1907) Wydział liczył 70 członków. Prezesurę objął wcześniej wspomniany S. Dzierzbicki, wiceprezesem został W. Marczewski, natomiast funkcję sekretarza powierzono prawnikowi, wybitnemu publicyście narodowo-demokratycznemu - Bohdanowi Wasiutyńskiemu. Do pracy w Wydziale dołączyli Wacław Potocki i Marian Kiniorski, których oddelegował Komitet CTR. W niespełna rok po uformowaniu się Wydziału kierownictwo objął M. Kiniorski. Zadania Wydziału zostały podzielone na dwie dziedziny: jedna dotyczyła badań ekonomicznych, a druga społecznych potrzeb rolnictwa i wsi. Początkowo badania stosunków ekonomiczno-rolnych na terenie Królestwa Polskiego nie miały szans. Główną barierą stała się ogólna obojętność, niechęć w stosunku do prac Wydziału zarówno ze strony członków, jak i ogółu rolników 59 . Duży nacisk Wydział Społeczno-Ekonomiczny CTR położył na rozpatrywanie projektów praw przygotowywanych przez ówczesny rząd oraz własnych wystosowywanych do władz państwowych przez Radę i Komitet. Wydział miał być „instytucją opiniodawczą o charakterze politycznym" w sprawach dotyczących ustroju rolnego i polityki agrarneje ${ }^{60}$.

Centralne Towarzystwo Rolnicze w ramach polityki społecznego oddziaływania na wieś dążyło także do wyłącznego kierowania szkolnictwem rolniczym na terenie Królestwa Polskiego. W związku z tym zaczęło opracowywać programy dla szkół i kursów. Organizowało kursy stałe i doraźne, które cieszyły się większą popularnością ze względu na dostosowanie czasu nauki do prac sezonowych w rolnictwie, a także ze względu na używanie języka polskiego jako wykładowego i nieskrępowanie kursów ze strony władz rosyjskich. W latach 1908 -I909 zostały zorganizowane I2-dniowe kursy rolnicze w głównej mierze skierowane do chłopów - członków kółek rolniczych i młodzieży wiejskiej. Uczestniczyło w nich ok. II8 osób. W kolejnych latach przy współuczestnictwie towarzystw okręgowych i kółek rolniczych działały 5-miesięczne kursy w Nałęczowie, w których uczestniczyło 46 osób. Od-

58 J. Socha, Centralne..., s. 44.

59 Sprawozdanie Centralnego Towarzystwa Rolniczego w Królestwie Polskiem za rok Igog..., s. I2-18; J. Socha, Centralne..., s. 57; H. Izdebski, Bohdan Wasiutyński 1882-1940, „Samorząd Terytorialny" $199 \mathrm{I}, \mathrm{nr}$, s. 4I-44.

60 J. Socha, Centralne..., s. 57-70. 
bywały się także io-tygodniowe kursy rolnicze dla młodzieży im. Promyka w Pszczelinie oraz jednomiesięczne kursy w Brześciu Kujawskim (25 osób), Liskowie ( 72 osoby), Chruszczewie (19 osób), Lublinie (74 osoby) i Sobieszynie (64 osoby). W 1908 r. zostały zorganizowane zimowe kursy, które zdaniem CTR miały częściowo zastąpić brak niższych szkół rolniczych. Kursy te odbywały się w takich miejscowościach, jak Lisków, Brześć Kujawski, Lipno, Miechów, Chruszczewo i Łuków. Ponadto 3-tygodniowe kursy odbywały się w Lublinie. Ogółem w kursach tych wzięło udział 368 słuchaczy. Uczestnikami kursów była młodzież w wieku od 16 do 19 lat, a także wiejscy działacze społeczni i oświatowi, abonenci pism dla ludu, takich jak „Zorza”, „Gazeta Świąteczna” czy „Przewodnik Kółek i Spółek Rolniczych”. Słuchaczami kursów byli także rolnicy - praktycy, dla których Sekcja Rolna w 1914 r. urządziła kurs ıo-dniowy. Wykłady odbywały się w szkole handlowej Edwarda Rontalera, przy ul. Polnej $36 \mathrm{w}$ Warszawie. Wysokość opłat za całość kursu wynosiła io rubli, a jedynie Członkowie Towarzystwa Wzajemnej Pomocy Pracowników Rolnych płacili 6 rubli. Przykładowy rozkład kursu umieszczony został w organie CTR - „Gazecie Rolniczej”'

Rok I9I3 w działalności CTR zaowocował powstaniem trzech szkół: dwóch męskich i żeńskiej. Jedną z nich Towarzystwo otrzymało od Mieczysława Kretkowskiego. Druga szkoła, męska, założona została w Liskowie przez ks. Wacława Blizińskiego oraz dwóch ziemian Ludomiła Pułaskiego i Zygmunta Siemiątkowskiego. Kolejną szkołą otrzymaną przez Towarzystwo była szkoła żeńska, której fundatorem była ziemianka Bronisława Karpowiczowa. Szkoła znajdowała się w Krzyżewie ${ }^{62}$.

6I S. Dzięciołowski, dz. cyt., s. I48-I49; J. Miąso, Szkolnictwo zawodowe w Królestwie Polskim w latach I8I5-1915, Wrocław 1966, s. 288-296; J. Socha, Dziatalność..., s. I5-17; Z Towarzystw i Instytucji Rolniczych, „Gazeta Rolnicza” 1914, nr I, s. I3.

62 Mieczysław Kretkowski - ziemianin, właściciel majątku ziemskiego koło Pokrzywnicy. Mając na celu podniesienie poziomu oświaty rolniczej na Ziemi Kutnowskiej, w czerwcu ı9ı r. zakupił od Jana Franciszka Czarnowskiego dwór z zabudowaniami oraz ponad 38 morgów ziemi parcelowanego majątku Wały pod Kutnem. Przez kolejne dwa lata ze środków własnych prowadził przebudowę budynków i I I I9I2 r. otworzył w Mieczysławowie roczną męską szkołę rolniczą. Uczył weterynarii, prowadził kadry i dbał o należyty rozwój placówki, z własnych zbiorów urządził szkolną bibliotekę. Cieszył się dużym uznaniem i zaufaniem zarówno ziemian, jak i włościan. Wacław Bliziński - proboszcz w Liskowie, społecznik i polityk. Postanowił utworzyć placówkę, która miałaby bezpośredni wpływ na rozwój gospodarstw chłopskich. Istniejące od $1907 \mathrm{r}$. kursy jedno- i trzymiesięczne dla mężczyzn i kobiet, cieszące się dużym powodzeniem wśród społeczności parafii liskowskiej, nasunęły mu myśl wzniesienia Szkoły Rolniczej. Projekt jej budowy złożył ks. Bliziński Centralnemu Towarzystwu Rolniczemu w Warszawie i uzyskał akceptację. Prace budowlane zakończone zostały w i913 r. Na podkreślenie zasługuje fakt, iż powstała z inicjatywy i przy udziale ks. W. Blizińskiego Szkoła Rolnicza była wówczas piątą tego typu placówką w Królestwie Polskim. Stanowiła ona nowoczesną instytucję oświatową, wyposażoną w: centralne ogrzewanie, oświetlenie elektryczne, wodociągi, sieć kanalizacyjną, wzorowo urządzoną mleczarnię, laboratorium mleczarskie, salę wykładową, a także internat dla czterdziestu uczniów. Zob.: http://www.info.kalisz.pl/biograf/blizinski.html [dostęp: 17 lutego 2020]. Ludomił Puławski - ziemianin, agronom, prezes RN Związku Ziemian. W czasie studiów w Rydze 
HALINA Bıtaty Rola i działalność Centralnego Towarzystwa Rolniczego w procesach modernizacyjnych...

TAB. 1 Plan dziesięciodniowego kursu dla rolników praktyków urządzonego przez Sekcję Szkolną CTR w Warszawie w dniach I4-24 I I9I4 r.

\begin{tabular}{|c|c|c|c|}
\hline Dzień & \multicolumn{3}{|c|}{ Godziny wykładowe } \\
\hline $\begin{array}{c}\text { Środa } \\
14 \text { I } 1914\end{array}$ & Gleboznawstwo & Zasady uprawy roli & $\begin{array}{c}\text { Chemia w zastosowaniu } \\
\text { do potrzeb rolnika }\end{array}$ \\
\hline $\begin{array}{c}\text { Czwartek } \\
15 \text { I } 1914\end{array}$ & $\begin{array}{c}\text { Uprawa łąk } \\
\text { i pastwisk }\end{array}$ & $\begin{array}{c}\text { Chemia w zastosowaniu } \\
\text { do potrzeb rolnika }\end{array}$ & Uprawa ąak i pastwisk \\
\hline $\begin{array}{c}\text { Piątek } \\
16 \text { I } 1914\end{array}$ & Gleboznawstwo & Melioracje łąkowe & $\begin{array}{c}\text { Chemia w zastosowaniu } \\
\text { do potrzeb rolnika }\end{array}$ \\
\hline $\begin{array}{c}\text { Sobota } \\
17 \text { I } 1914\end{array}$ & - & $\begin{array}{c}\text { Melioracje ląkowe. } \\
\text { Studnie }\end{array}$ & Choroby zakaźne zwierząt \\
\hline $\begin{array}{c}\text { Poniedziałek } \\
19 \text { I } 1914\end{array}$ & - & $\begin{array}{c}\text { Zasady żywienia zwierząt } \\
\text { gospodarskich }\end{array}$ & Opasanie inwentarzy \\
\hline $\begin{array}{c}\text { Wtorek } \\
20 \text { I } 1914\end{array}$ & $\begin{array}{c}\text { Opasanie } \\
\text { inwentarzy }\end{array}$ & Mleczarstwo & Drenowanie \\
\hline $\begin{array}{c}\text { Środa } \\
21 \text { I } 1914\end{array}$ & Mleczarstwo & Nawożenie roli & - \\
\hline $\begin{array}{c}\text { Czwartek } \\
22 \text { I } 1914\end{array}$ & Płodozmiany & Nawożenie roli & Prawodawstwo weterynaryjne \\
\hline $\begin{array}{c}\text { Piątek } \\
23 \text { I } 1914\end{array}$ & - & Folwarczne straże ogniowe & Choroby zakaźne zwierząt \\
\hline $\begin{array}{c}\text { Sobota } \\
24 \text { I } 1914\end{array}$ & Ratownictwo & Hodowla drzew leśnych & Hodowla drzew leśnych \\
\hline
\end{tabular}

Źródło: S. Jankowski, Nowy typ uczelni rolniczej, „Gazeta Rolnicza” 1925, nr 46, s. 1275-I276.

Nauka w szkołach rolniczych CTR była bezpłatna, uczniowie ponosili koszty tylko za swe utrzymanie. W przypadku kursu II-miesięcznego kwota ta wynosiła od 60 do $80 \mathrm{rb}$., na co nie zawsze było stać przeciętną chłopską rodzinę. Dlatego zaczęto pozyskiwać fundusze od społeczeństwa, a szczególnie od ziemiaństwa. Warto wspomnieć, iż na cele oświaty rolniczej państwo zaborcze udzielało skromnych dotacji ${ }^{63}$.

Oprócz zakładania szkół i kursów dużą rolę odegrały wystawy oraz pokazy rolnicze. Pierwszą wystawę CTR zorganizowało jesienią I907 r.

prezes Polskiej Korporacji Akademickiej „Arkonia”. Po 1905 r. wspierał działalność ks. W. Blizińskiego w Liskowie, finansując m.in. szkołę rolno-mleczarską. Członek Komitetu CTR. (W. Roszkowski, Lista największych wtaścicieli ziemskich w Polsce w r. 1922, „Przegląd Historyczny” 1983, t. 74, s. 294). Zygmunt Siemiątkowski - ziemianin, pochodził z Męckiej Woli (pow. sieradzki). Aktywny działacz CTR, współtwórca męskiej szkoły w Liskowie (W. Karczewski, Lisków. Dzieje jednej wsi polskiej, Kraków 1937, s. 72-73).Zob. też: Z Towarzystw i Instytucji Rolniczych, „Gazeta Rolnicza” 1912, nr 25, s. 255.

63 J. Socha, Dziatalność..., s. 17-20. 
w Ciechanowie. Od tej pory Towarzystwo urządziło jeszcze kilka wystaw, które, jak się okazało, miały wpisać się na stałe w jego rolniczo-oświatową działalność. Początkowo były to pokazy jednodniowe. W skład komitetu wystawowego wchodzili przeważnie ziemianie, do których zaczęto stopniowo włączać także chłopów ${ }^{64}$. W I909 r. CTR urządziło I6 pokazów, na których wystawiono ok. 669 koni i 849 sztuk bydła. Natomiast rok później podczas I 4 pokazów wystawiono I 250 sztuk koni i 840 sztuk bydła. Koszty zorganizowania pokazów, wystaw nie były małe. Wydatki związane były z przygotowaniem stanowisk, wynagrodzeniem komisji sędziowskiej, zakupem pasz, opłaceniem stróży oraz na nagrody. Sumy składające się na nagrody pochodziły $z$ darów i zapomóg od osób prywatnych i instytucji oraz z kasy państwa. Nagrody te przyznawano w postaci rzeczowej i gotówce ${ }^{65}$. Najważniejsze wartości oświatowe CTR przypisywało nagrodom w postaci czasopism i książek o tematyce rolniczej. Stanowiły one tzw. premie rzeczowe służące rozwijaniu zainteresowań czytelniczych wsi. Warto wspomnieć, że w I9I2 r. Okręgowe Towarzystwo Rolnicze w Sobieszynie, na wystawie urządzonej w Rykach, opłaciło w ramach nagrody pieniężnej roczną prenumeratę „Przewodnika Kółek i Spółek Rolniczych”. Chłopi nie zawsze byli zadowoleni z takich nagród, zabiegali bowiem o nagrody pieniężne, które, jak się później okazywało, przepijali lub wydawali bez widocznych korzyści edukacyjnych ${ }^{66}$.

Frekwencja na tego rodzaju „imprezach” zależała od wielu czynników, w tym od aury. W dni pogodne było więcej zwiedzających, aniżeli podczas mniej sprzyjających warunków atmosferycznych. Nie zawsze jednak niekorzystna aura była w stanie odstraszyć zwiedzających. Może o tym świadczyć pokaz maszyn rolniczych w Wilanowie w I9I2 r., który cieszył się dużą frekwencją pomimo deszczowej pogody. Innym przykładem może być wystawa rolnicza w Jędrzejowie w 1913 r., gdzie było ok. 27 tys. zwiedzających. Wśród nich znaleźli się nie tylko okoliczni mieszkańcy, ale także chłopi i ziemianie $\mathrm{z}$ dalszych okolic ${ }^{67}$.

Działalność oświatowa CTR polegająca na urządzaniu wystaw i pokazów przerwana została wraz z wybuchem I wojny światowej, a wznowiono ją dopiero w I92I r. podczas pokazu owoców i narzędzi rolniczych w Warszawskim Ogrodzie Pomologicznym ${ }^{68}$.

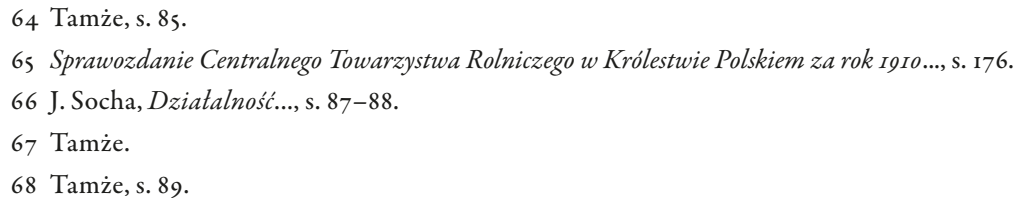


Od początku swego istnienia CTR urządzało wycieczki rolnicze. Wycieczki te organizowane były początkowo dla ziemian, ponieważ chłopi wzbraniali się od podróży. Niechęć do udziału w wycieczkach spowodowana była brakiem odpowiednich funduszy oraz hamowaniem prac polowych podczas nieobecności w gospodarstwie. Dopiero od ı909 r. zauważamy pierwsze masowe grupy chłopów zwiedzających wystawę rolniczą pod Jasną Górą. Nie należy się temu jednak dziwić, bowiem odwiedzili przy okazji częstochowskie sanktuarium maryjne. Chłopi objęci oddziaływaniem kółek rolniczych CTR najczęściej zwiedzali stacje i pola doświadczalne, bywali na pokazach rolniczych, wystawach, zwiedzali wzorowe wsie i folwarki. Po zwiedzeniu pól i stacji doświadczalnych uczestnicy zwykle udawali się do szkół rolniczych. Przykładem może być wyprawa ze stacji doświadczalnej w Kutnie do Mieczysławowa i Mirosławic. Ze stacji w Chruszczewie udano się natomiast wprost do Kruszynka oraz Sobieszyna, gdzie znajdowała się stacja i szkoła. W latach I9II-I9I4 CTR zorganizowała wycieczki na tzw. ziemie zabrane, czyli na Podole i Żmudź, a w I9I4 r. na Litwę

Przeprowadzanie intensyfikacji rolnictwa wymagało, zwłaszcza wśród chłopów, szybkiego spopularyzowania umiejętności nowoczesnego gospodarowania na roli. W tym celu w 1908 r. dla drobnych rolników zorganizowano pierwsze wycieczki zagraniczne do Szwecji i Danii ${ }^{70}$. Wycieczki miały zaznajamiać z rozwojem europejskiego rolnictwa, z rozwiniętą tam siecią stowarzyszeń i związków rolniczych oraz z wysokim poziomem oświaty. Drugi kierunek organizowanych przez Towarzystwo wycieczek wiódł na Morawy i do Czech. W wycieczce uczestniczyła 5I-osobowa grupa członków kółek rolniczych CTR, która mogła liczyć na pomoc czeskich producentów rolnych zrzeszonych w tamtejszych organizacjach rolniczych. W Czechach zwiedzano wsie Běstovice, Bohdaneč i Vyšehněvice, które stawiano za wzór, oraz miasto Pardubice, gdzie wytwarzano artykuły przemysłowe. $\mathrm{Na}$ Morawach zwiedzano średnią szkołę rolniczą w Přerovie oraz trzy niższe szkoły rolnicze w Kroměřížu. Dalsza trasa wycieczki wiodła do wsi Przykazy, gdzie zwiedzano wzorcowe gospodarstwa i to zarówno te małe, jak i duże. W gospodarstwach tych dokonano „uszlachetniania” bydła, co wiązało się z większą mlecznością krów. Zwiedzający zainteresowani byli głównie spółdzielniami rolniczymi, zakładami przetwarzającymi płody rolne oraz browarami, gorzelniami, cegielniami, elektrowniami oraz magazynami zbożowymi. Zasadniczym celem organizowanych przez CTR wycieczek rolniczych było

69 Sprawozdanie Centralnego Towarzystwa Rolniczego w Królestwie Polskiem za rok Igog..., s. 9-ı; J. Socha, Dziatalność..., s. 97-98.

70 S. Dzięciołowski, dz. cyt., s. I23; J. Socha, Dziatalnośćc..., s. 98. 
naoczne pokazanie zwiedzającym, że gospodarka chłopska może wspiąć się na wyższy poziom bez ingerencji w stosunki własnościowe ziemi $^{{ }^{1 x}}$. W grupie wycieczkowej nastało przekonanie o dobroczynnych skutkach oświaty rolniczej. Latem I9ı2 r. zorganizowano ponownie dla chłopów wycieczkę do Czech i Moraw. Celem zwiedzania były dwie wzorowe wsie: Rokycany i Sány oraz wcześniej wspomniane Przykazy. Uwaga zwiedzających skupiła się na: spółkach hodowlanej i handlowej, kasie pożyczkowo-oszczędnościowej, domu ludowym, straży ogniowej, miejskiej łaźni oraz szkole początkowej ${ }^{72}$.

Przemiany społeczno-gospodarskie, jakie dokonywały się na terenie Królestwa Polskiego po I864 r., wymuszały na grupach dysponujących dostatecznymi zasobami ekonomicznymi zaangażowanie się w modernizację polskiej wsi ${ }^{33}$. Poczynania te skupiły się przede wszystkim w Centralnym Towarzystwie Rolniczym oraz w licznych jego wydziałach i sekcjach, w których prowadzone były akcje szkoleniowe i propagandowo-informacyjne. Centralne Towarzystwo Rolnicze utworzone zostało w dużej mierze dla obrony interesów gospodarczych własności folwarcznej, a także towarowego gospodarstwa chłopskiego. W centrum zadań programowych wpisała się głównie popularyzacja wiedzy rolniczej oraz poczucie narodowej łączności włościan z resztą ziemiaństwa ${ }^{74}$.

\section{Bibliografia}

\section{Źródła drukowane}

„Gazeta Rolnicza” 1907, I911, I912, 1914

Pamiętnik Towarzystwa Rolniczego Krakowskiego za czas od r. I845 do r. I895, zestawil J.A. Lippoman, Kraków i 898 .

„Przewodnik Kółek i Spółek Rolniczych Królestwa Polskiego” I9I2

Rocznik Statystyczny Królestwa Polskiego z uwzględnieniem innych ziem polskich, pod kier.

E. Strasburgera, Warszawa i9i6.

Sprawozdanie Centralnego Towarzystwa Rolniczego w Królestwie Polskiem za rok Igog, Warszawa i9io.

Sprawozdanie Centralnego Towarzystwa Rolniczego w Królestwie Polskiem za rok Igı, Warszawa I9II.

71 Tamże, s. I02-IO3.

72 W. Bzowski, Wrażenia z wycieczki do Czech i na Morawy, „Przewodnik Kółek i Spółek Rolniczych Królestwa Polskiego", 22 VIII I9I2.

73 I. Krasińska, dz. cyt., s. 106.

74 A. Żabko-Potopowicz, Stulecie dziatalnościziemiaństwa polskiego I8I4-19I4, Warszawa 1929, s. 56-57. 
HALINA BıAtY Rola i działalność Centralnego Towarzystwa Rolniczego w procesach modernizacyjnych...

Sprawozdanie Centralnego Towarzystwa Rolniczego w Królestwie Polskiem za rok IgII, Warszawa 1912.

„Tygodnik Ilustrowany” 1907

Ustawa Centralnego Towarzystwa Rolniczego w Królestwie Polskim, Warszawa 1907.

\section{Opracowania}

Biały H., Rola pól doświadczalnych w rozwoju rolnictwa Królestwa Polskiego iziem zabranych wXIX i początkach XX wieku, „Zeszyty Wiejskie” 2013, z. I8.

Borkowski J., Gurwicz A., Kótka rolnicze w II Rzeczypospolitej, Warszawa 1978.

Dzięciołowski S., Centralne Towarzystwo Rolnicze w Królestwie Polskim i jego polityka agrarna $1906-1918$, Warszawa 1981.

Gloger Z., Pisma rozproszone (I89o-I9I0), t. III, Białystok 2016.

Grabski W., Historia Towarzystwa Rolniczego 1858-186I r., t. 2, Warszawa 1904.

Izdebski H., Bohdan Wasiutyński 1882-1940, „Samorząd Terytorialny” 1991, nr 5.

Kaczmarek Z., Marszatkowie Senatu II Rzeczpospolitej, Warszawa 1992.

Karczewski W., Lisków. Dzieje jednej wsi polskiej, Kraków 1937.

Kaszubowski P., Potężny w duchu i potężny w ciele. Opowieść o Stanistawie Chetchowskim, Przasnysz 2007.

Kopczyński W., Polski Stownik Biograficzny, t. vi, Kraków 1937.

Krasińska I., Rola i dziatalność Okregowego Towarzystwa Rolniczego w Radomiu w modernizowaniu wsi guberni radomskiej w latach Igo6-IgI4, [w:] Dwór-wieś-plebania na ziemiach polskich wXIX i XX wieku. Profesorowi Mieczystawowi B. Markowskiemu w trzydziestolecie pracy naukowej, red. W. Caban i in., Kielce 2003.

Leśniowski S., Chaniewski Stanistaw, [w:] Polski Stownik Biograficzny, t. 3, Kraków 1937.

Miąso J., Szkolnictwo zawodowe w Królestwie Polskim w latach I8IS-I9IS, Wrocław 1966.

Mysiakowski M., Spotecznik z Klic, czyli rzecz o Michale Ignacym Bojanowskim (I865-1932), „Rocznik Mazowiecki” 2006, t. 18.

Przegaliński A., Zarys dziatalności oświatowej Lubelskiego Towarzystwa Rolniczego w latach I905-1914, „Studia z Historii Społeczno-Gospodarczej” 2010, t. VII.

Roszkowski W., Lista największych wtaścicieli ziemskich w Polsce w r. 1922, „Przegląd Historyczny" 1983 , t. 74 .

Snoch B., Stownik szkolny. Terminy i pojęcia historyczne, Warszawa 1990.

Socha J., Centralne Towarzystwo Rolnicze 1907-1927, Łódź 2011.

Socha J., Dziatalność Centralnego Towarzystwa Rolniczego w dziedzinie oświaty rolniczej 1907-1927, Łódź 1994.

Socha J., Stownik biograficzny dziataczy Centralnego Towarzystwa Rolniczego (1907-1929), Łódź 2003.

Ścibor E., Życie i dziatalnośćspoteczno-obywatelska Leona Przanawskiego (I844-1914), „Bibliotekarz Lubelski” 20IO, R. LVIII.

Wojciechowski S., Historia spótdzielczości polskiej od IgI4 roku, Warszawa 1939.

Wykrętowicz S., Przemyst cukrowy i jego rola w ekonomice Polski Ludowej (I945-1960), Poznań 1967.

Żabko-Potopowicz A., Stulecie dziatalności ziemiaństwa polskiego I8I4-19I4, Warszawa 1929.

\section{Źródła internetowe}

http://www.info.kalisz.pl/biograf/blizinski.html 
Streszczenie: Artykuł przedstawia rys historyczny i różne aspekty działalności Centralnego Towarzystwa Rolniczego (CTR) w Królestwie Polskim. Oficjalnie zainaugurowało działalność II III 1907 r. wzorem wcześniejszych zrzeszeń rolniczych, podejmując działania mające na celu modernizację rolnictwa i wsi w istniejących politycznych, społecznych oraz gospodarczych realiach zaboru rosyjskiego. Uzyskawszy rządowe pozwolenie na rozpoczęcie działalności, CTR prowadziło politykę gospodarczą oddziałującą na rynek towarowy i rynek pracy. W jej ramach funkcjonowały wydziały: Kółek Rolniczych, Społeczno-Ekonomiczny, Rolniczy, Hodowlany i Naukowo-Dydaktyczny, które realizowały zadania, mając na uwadze unowocześnienie i usprawnienie polskiego rolnictwa. Działalność przejawiała się m.in. w organizacji jarmarków, na których prezentowano np. inwentarz żywy czy maszyny rolnicze, ponadto organizowano odczyty, kursy, wycieczki rolnicze, podejmowano starania o szkolnictwo rolnicze na dobrym poziomie oraz propagowano prasę i książki na temat rolnictwa. Prowadzono też stacje i pola doświadczalne. Po zakończeniu I wojny światowej CTR skoncentrowało się na naprawie szkód wyrządzonych przez działania wojenne. Towarzystwo chwalebnie zapisało się w dziejach polskiego rolnictwa w aspekcie jego modernizacji i integracji środowiska związanego z polską wsią.

Słowa klucze: Centralne Towarzystwo Rolnicze, rolnictwo, oświata

Summary: The article presents a historical outline and various aspects of the activity of the Centralne Towarzystwo Rolnicze in the Kingdom of Poland. The Society officially inaugurated its activity II III 1907 and, following the earlier farmers' associations, took action aimed at modernizing the agriculture and the rural areas in the existing political, social and economic realities of the Russian occupied territories, i.e. the territories that after the partitions of Poland were under Russian rule. After the authorities had granted it permission to go ahead with its activity the cas pursued an economic policy that affected the commodities and labor markets. This policy was realized by the following sections of the Society: the Farmers' Cooperatives Section, the Social and Economic Section, the Agricultural Section, the Breeding Culture Section and the Experimental and Didactic Section, all of which performed their tasks with a view to modernizing the Polish agriculture and making it more effective. Their activity consisted, inter alia, in holding fairs, at which e.g. livestock and agricultural machines were exhibited. The Society organized lectures, courses, excursions for farmers and made efforts aimed at spreading high standard agricultural education. It popularized periodicals and books dealing with agricultural issues as well. Moreover, the Society ran some experimental stations and had some pieces of land for experiments. After WWI the CTR focused on undoing the damage that had been done by the war. The Society made a creditable mark on the history of the Polish agriculture with regard to its modernization and the integration of the rural population.

Keywords: Centralne Towarzystwo Rolnicze, agriculture, education 